\title{
Multimodal Texts of Political Print Advertisements in Ukraine
}

\author{
Zoriana Batrynchuk ${ }^{1}$, Nadia Yesypenko ${ }^{1}$, Ihor Bloshchynskyi ${ }^{2}$, Kostiantyn Dubovyi ${ }^{2}, \&$ Olena Voitiuk $^{2}$ \\ ${ }^{1}$ Department of English, Yurii Fedkovych Chernivtsi National University, Chernivtsi, Ukraine \\ ${ }^{2}$ Foreign Languages Department, Bohdan Khmelnytskyi National Academy of the State Border Guard Service of \\ Ukraine, Khmelnytskyi, Ukraine \\ Correspondence: Ihor Bloshchynskyi, Foreign Languages Department, Bohdan Khmelnytskyi National Academy of \\ the State Border Guard Service of Ukraine, Khmelnytskyi, Ukraine.
}

Received: December 13, 2021

Accepted: January 13, 2022 Online Published: January 25, 2022

doi:10.5430/wjel.v12n1p115

URL: https://doi.org/10.5430/wjel.v12n1p115

\begin{abstract}
Political print advertisements as an integral part of political propaganda contribute to creating a positive image of a politician or political party aiming to win popular votes. The effective combination of verbal and non-verbal (pictorial) components presupposes a purposeful influence on the electorate by means of activating existing socio-cultural schemas among voters. This study aims to analyze the generic structural potential of political print advertisements in Ukraine and to interpret the symbolic representation of the verbal and non-verbal levels of political advertisements. The data, encompassing 25 leaflets, was collected in 2020 during the local election campaign in Chernivtsi, Ukraine. The analysis has been conducted on two levels: literal and interpretative. Following the principles of Generic Structure Potential of advertisements (Cheong, 2004) we have outlined the GSP of print political advertisements in Ukraine. Thus, non-verbal (visual) components incorporate the lead (Locus of Attention (LoA) and Complement to the Locus of Attention (Comp.LoA) emblem, pictogram, verbal (linguistic) components involve Announcement (Opening), Enhancer, Slogan, and Call-and-visit Information. The next level of the analysis presupposed the interpretation of the obtained results. In accordance with this, the symbolic representation of the verbal level of political advertisements, incorporating patriotic, social, economic, and political slogans has been revealed. In terms of the symbolic representation of the non-verbal level of political advertisements, we observe the following in the analyzed material: the photo of the candidate, appearance, pictograms, and additional pictorial elements. The results indicate that the displays of the analyzed material are often congruent and explicit. Cases of incongruent and implicit displays have been observed as well. Such advertisements boost viewers' curiosity as they contain less verbal information. The results of the election show that the candidates whose advertisements incorporated symbolism and greater non-verbal information, led among the popular votes.
\end{abstract}

Keywords: multimodality, multimodal texts, political print advertisements, symbolism, graphic narration, generic structure potential

\section{Introduction}

Over the past two decades, there has been a growing interest in the phenomenon of multimodality. Modern print political advertisements usually consolidate verbal and non-verbal (pictorial) components (modes). Being of multimodal nature, such advertisements serve to communicate a certain message.

The notion of multimodality was developed in the mid-1990s, following the principles of Functional Linguistics and Social Semiotics. The latter was approached by M. Halliday. According to Halliday, language is a product of social process; the resources of a language are shaped by the functions it has developed to satisfy the communicative needs of people's lives (Halliday, 1978). The theory was further elaborated by R. Hodge and G. Kress. Within the scope of Traditional Semiotics, the codes are impersonal and universal, whereas the rules of Social Semiotics presuppose that the meaning encoded by the author and the meaning decoded or interpreted by the addressee in a single text may not coincide. As Hodge \& Kress (1988) presume: it is the struggles and their uncertain outcomes that must be studied at the level of social action, and their effects in the production of meaning. The scholars were mainly focused on writing and images in print media. Kress \& van Leeuwen (2006) attempted to elaborate the existing traditional viewpoint suggested by Halliday, providing a multimodal approach to visual communication. In their work, the scholars described representational, compositional and interactive meanings. Jewitt, Bezemer, and O'Halloran (2016) 
argue, that the notion of multimodality should be viewed taking into account its interdisciplinary "appearances":

Multimodality questions that a strict 'division of labour among the disciplines traditionally focused on meaning-making, on the grounds that in the world we're trying to account for, different means of meaning-making are not separated but almost always appear together: image with writing, speech with gesture... It is that recognition of the need for studying how different kinds of meaning-making are combined into an integrated, multimodal whole. (p.2)

Image schemas theory could complement more stable concept theories by incorporating contextual elements. Image schemas are grounded on human's emotional interrelations, motor programmes and bodily experiences which impact comprehension (Yesypenko et al., 2022). While reading texts, readers can understand non-physical concepts on the basis of their own actions and characteristics. For example, viewing something as abstract as 'happiness' in human terms has a descriptive and explanatory power in the way that makes sense to readers (Soloviova et al., 2021). Authors conducted a qualitative analysis and compared the number of critical elements in the written text commentaries, namely: three themes were generated for the first question ('criticism', 'thorough reading', and 'thoughtful reading') and three themes for the second one ('to disagree', 'to evaluate', and 'to foster consideration') (Hromova et al., 2022).

O'Halloran (2016), when defining "multisemiotic' also notes the significance of the combination of different resources, each with their own potential. The dichotomy of verbal/non-verbal communication, which presumes the dominance of verbal and to some degree underrates other aspects of meaning-making, is no longer favored by the researchers. Instead, meaning is considered holistically, incorporating various elements. O'Halloran (2016) also formulates three key premises of multimodality:

1. Meaning is made with different semiotic resources, each offering distinct potentials, and limitation.

2. Meaning-making involves the production of multimodal wholes.

3. If we want to study meaning, we need to attend to all semiotic resources being used to make a complete whole.

\section{Theoretical Background}

The Social Functional theory has been approached by scholars to analyze semiotic resources. The list of such resources is constantly expanding due to the emerging combinations of modes and of new forms of print and media. The semiotic resources include but are not limited to visual images, music and sound, movement and gesture, video texts, internet sites, and 3-D sites. The notion of 'multimodality' has emerged, referring to the combination of multiple modes (spoken, written, printed, and digital media, embodied action, 3-D material objects, and sites) through which social semiosis takes place (O’Halloran, 2009).

Kress (2011) contends: "Multimodality" names the field in which semiotic work takes place, a domain for enquiry, a description of the space, and of the resources that enter into meaning in some way or another" (p. 38). All modal resources available in a culture should be viewed holistically, as one integrated field - resources for meaning-making. The scope of interest of the multimodal approach is to view the joint modes as:

One connected cultural resource for meaning-making by members of a social group at a particular moment. ... Each [mode] therefore needs to be dealt with as requiring apt descriptive categories which arise from the difference. Therefore, multimodal discourse analysis needs to encompass all modes used in any text or text-like entity, with each described both in terms specific to its material and historical affordances and in terms shared by all modes. (Kress, 2011, p. 38)

In accordance with this, we may assert that advertisements have great potential for multimodal analysis as their graphic narration is vivid. The major aim of any advertisement in print or media is to attract the viewer's attention. The layouts of advertisements consolidate verbal and non-verbal (pictorial) modes serving to persuade, entertain, and engage the addressee. In order to lead the addressee into the bigger world of information about the advertised product, the phenomenon of hypertextuality is quite common. It takes the reader into the digital environment, where he can encounter verbal and multimodal information. Taking on various "hypertextual paths" the addressee can structure texts online and integrate elements of video, audio, and images (Garcia \& Abuin, 2019).

Political advertising (PA), which is one of the most widely-used instruments, particularly during electoral periods, is a communication planned and implemented by a political party or candidate by purchasing advertising time and space in communication media and in various forms of media content such as radio and television to deliver political messages to influence the attitudes, behaviors and political beliefs of voters (Tokgöz, 2010). PA is one-way communication, where a person, entity, or agency acts as a sender, encoding the necessary information to influence 
the voters. It is highly important for the sender to have a successful try and to reach the desired effect.

Generally, political candidates or parties may implement two kinds of advertisements: negative and positive. The latter refers to the form of communication where the political candidate's promises, actions, and even features of character are outlined to the voters in a positive, optimistic light, showing the potential of the glittering future. On the contrary, negative political advertisements serve to highlight the political opponent's inconsistencies in promises, various elements of criticism, embodied in sarcastic content. It may be presented in an explicit or implied manner, criticizing even personal flaws, speech defects, or privacy items (Alp, 2016). This article focuses on positive political advertisements.

In this study, we aim to investigate the political advertising in Ukraine in terms of its Generic Structure Potential and to interpret the contextual schemas involved.

\section{Methods and Materials}

The methodology of conducting the research follows the principles of Systemic Functional Approach, Generic Structure Potential (GSP) of print advertisements, offered by Cheong (2004) and accounts for the analysis of the constituents of the multimodal print advertisement (including visual and linguistic constituents) to construct their meaning. The visual components include the Lead and Display, and linguistic aspects include Announcement (Opening), Enhancer, and Call-and-visit Information.

Within GSP, the Lead considers the Locus of Attention and Complements to the Locus of Attention. The Locus of Attention is an attention-seeking element, "textually a springboard for further development of the central idea" (Cheong, 2004, p. 165). The same central idea may be reiterated in the linguistic component of the advertisement. Complements to the Locus of Attention are viewed as less salient than the Locus of Attention, playing a subordinate role to enhance the Locus of Attention. Display can be explicit (the advertised product and the LoA coincide), implicit (the advertised product is intangible, given a tangible form through another medium), congruent (symbolism isn't involved in the advertisement), or incongruent (the advertised product is realized through symbolism). Emblem may take on linguistic (realizing in the form of the name of the product) or visual form (realizing through the product logo).

The most salient linguistic element is the Announcement. An Enhancer may create or modify the meaning created by the Lead and the Announcement. Additional verbal information about the product that is not included in the Enhancer may be identified as Call-and-visit Information. It is non-salient, usually in small print, but its presence may increase the credibility of the advertised product.

Thus, the interaction of the visual and linguistic components of the print advertisements creates Interpersonal, Ideational, and Textual meaning. Bowcher (2016), Savitri (2019), Knox \& Hao (2020) (Systemic Functional), Gao (2020), Pacheco-Costa \& Guzman-Simon (2020) have utilized multimodal text analysis when analyzing different types of multimodal texts, including advertisements and children's written multimodal texts. The aspects of visual communication and cultural features were tackled by Dorofeev \& Tomascikova (2019), Kovalevska \& Bekhta (2019), Finn (2011).

For this study, the authors analyzed 25 leaflets and newspaper advertisements. The data had been collected during the local election campaign in Chernivtsi, Ukraine in 2020. The analysis has been conducted on the following levels:

1. Literal level, following the principles of Generic Structure Potential of print advertisements. Here we attempt to outline the peculiarities of the layout of the analyzed materials and the combination of verbal and pictorial elements.

2. Interpretative level, where we decode the message of the multimodal material, discussing the schemas and sociocultural attributes embedded in verbal components and graphic narration. This article explicates 10 examples of multimodal material.

\section{Data Analysis}

To reveal the socio-cultural and schematic aspects of multimodal political advertisements, one should analyze their structure. In line with this, we turn to the Generic Structure Potential, suggested by Cheong (2004), aiming to analyze the interaction between visual and linguistic components. This study, focusing on political advertisements, shows that the material lacks some of the components to utilize the aforementioned approach. Thus, focusing on our material and having generalized the components of the PA, we can outline the following generic structure potential of print political advertisements in Ukraine:

1. (Non-verbal) Visual components: Lead (encompassing Locus of Attention (LoA) and Complement to the Locus of Attention (Comp. LoA;) emblem, pictogram. 
2. (Verbal) Linguistic components (Announcement (Opening), enhancer, slogan, call-and-visit information).

The display and its features (implicit (metaphorical)/explicit/) will be further discussed in the second part of the analysis.

\subsection{Literal Level}

The lead, the most salient component in the analyzed material, serves to attract the viewer's attention. When approached without the other component of the advertisements, the lead might say almost nothing about the case. In the analyzed PA, the lead is almost always represented by the photograph of the political candidate. The photos can differ in size and orientation (centered, right-centered, or left-centered), but almost always call attention. The most commonly used option is a left-centered photo representing a neat-looking, smartly dressed person with a friendly smile. Being the Locus of Attention, it aims to attract the viewer's eye to engage him into reading and finding out more about the candidate. Many PAs show scarce usage of Complements to Locus of Attention. However, some depict the national flag, emblem of the affiliated party, or famous buildings (see Figures 1,2, 7).

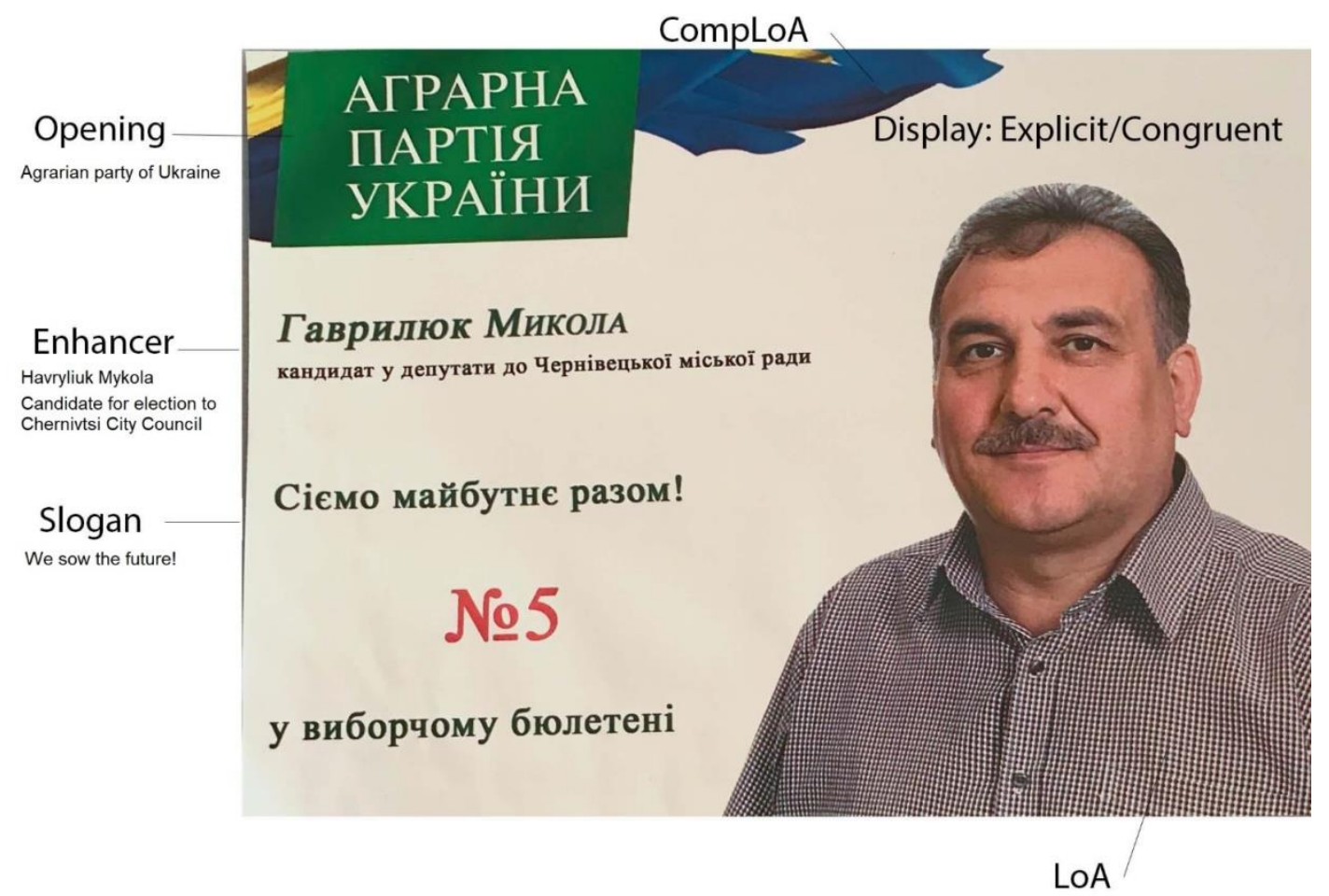

Figure 1. Multimodal Text of PA in Ukraine

Emblem. As it was an election campaign for the local council, almost all of the candidates had affiliation with the parties currently running in the country. Thus, emblems in the political advertisements stand for the party. Often such emblems can take on the form of a Complement to the Locus of Attention, being a background depiction (Figure 2) or they take the opening position (Figure 5).

Pictogram. Having generalized the set of advertisements, we may state that the most common pictogram is a 'checkmark in the box' often combined with verbal information, serving as an enhancer to instruct the voters how to make their choice, favoring the candidate in the advertisement.

The other case of pictogram usage refers to the candidate and the party, who provided a list of non-verbal elements referring to the items or actions that have been done or are to be done in the city. To decipher the pictogram one should consult the candidate's memo, which includes an explanation of all 27 pictograms (Figure 6, Figure 6.1) that stand for the amount of money spent to modernize and improve the city. This memo was presented by the political party of the incumbent city mayor and aimed to inform voters of the achievements of the party to suggest the candidate's potential to continue improving the city. 


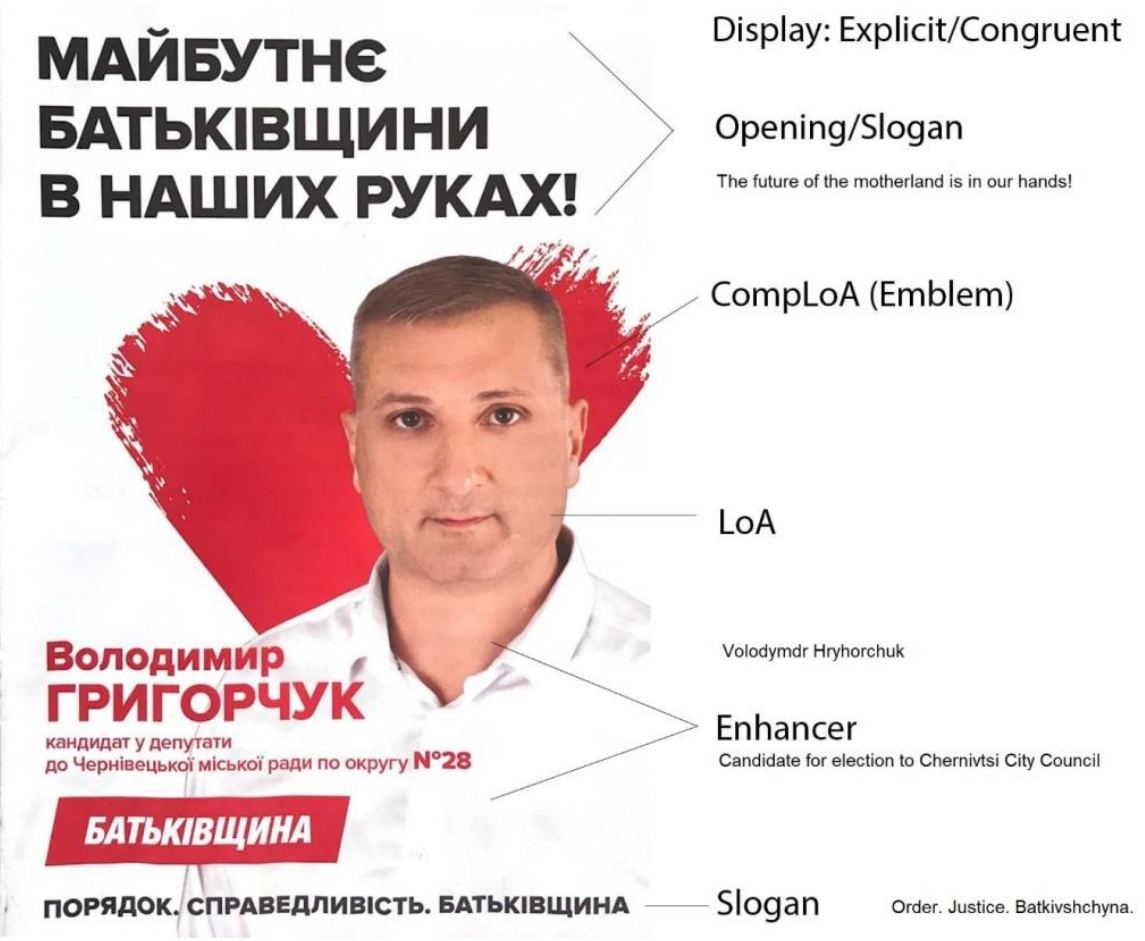

Figure 2. Multimodal Text of PA in Ukraine

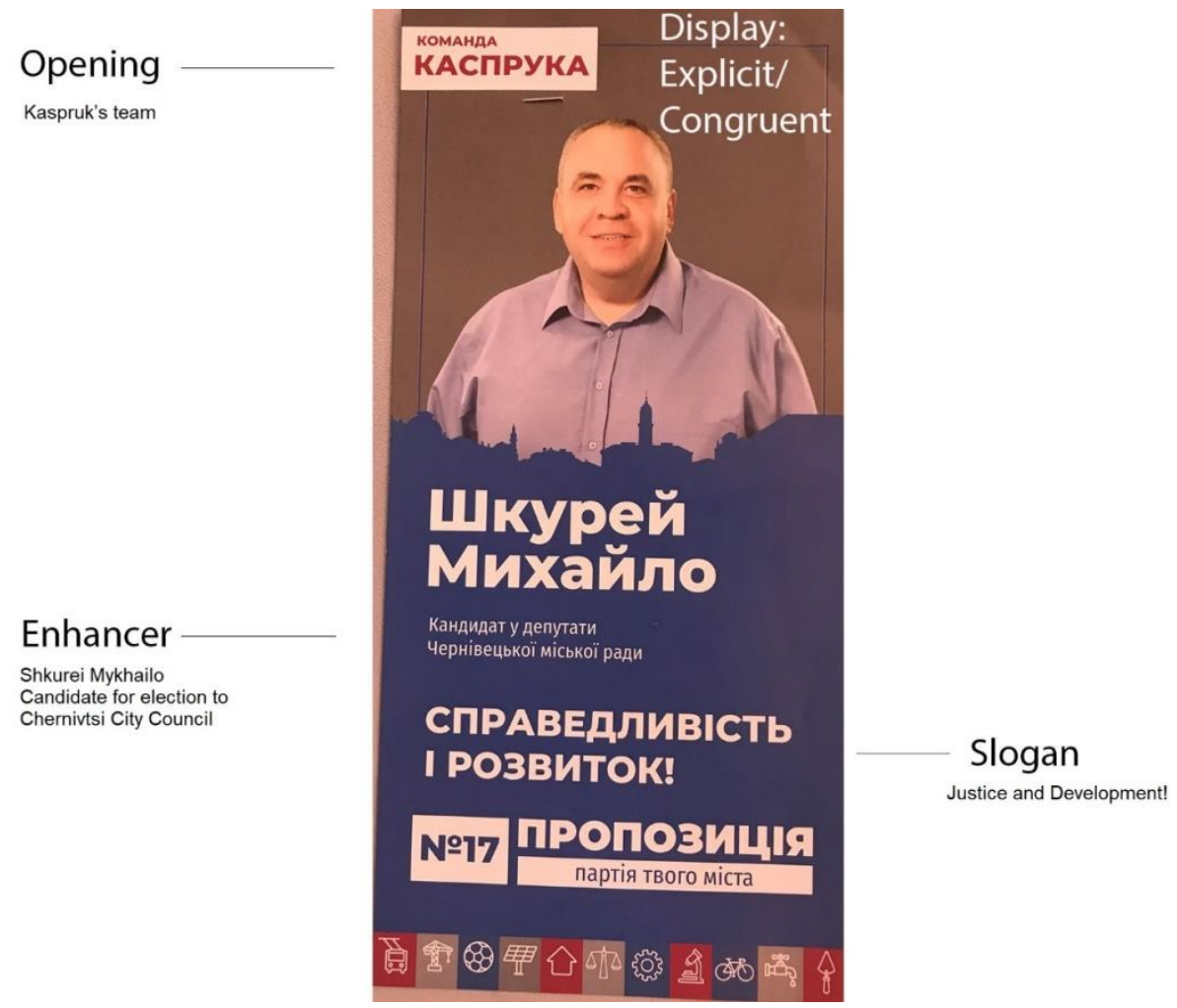

Figure 3. Multimodal Text of PA in Ukraine

Regarding the opening as a linguistic component of the analyzed material, we observe the following cases: -the name of the candidate;

-the corresponding number in the voting paper; 
-name of the party (affiliation);

-other.

"Other" might include the titles of the campaign or short sentences to evoke patriotism.

The opening information is often catchy, in bold type, upper case, and distinctive colour. The verbal component serves to draw the viewer's eye. Most of the analyzed advertisements provide the affiliation of the candidate to indicate that he shares the party's ideas, only then the candidate's name follows (Figure 5). Interestingly, the corresponding number of the candidate serves as an opening of the advertisement, for it might be extremely important to make the voter remember the number first, and only then get acquainted with the candidate (his name) and affiliation.

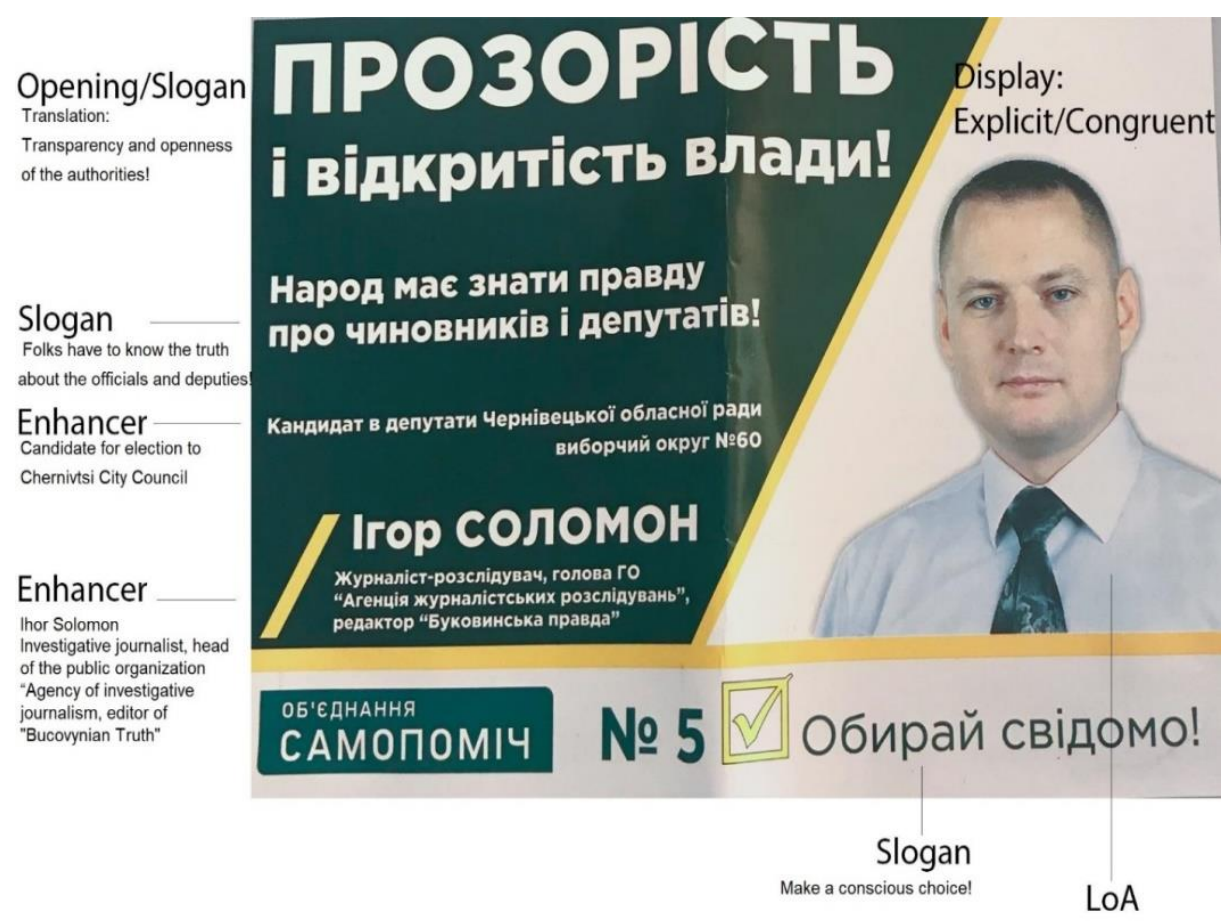

Figure 4. Multimodal Text of PA in Ukraine

Enhancer. The enhanced information about the candidate is represented through the additional indication of the candidate's occupational, familial, or demographic details: his current occupation is presumably used to ensure the voter that his choice would be correct. However, in most cases the enhancer is combined with pictograms to instruct the viewer how to vote, by reproducing a part of the voting paper with the list of the several 'neighboring' candidates, using bold type to enhance the target candidate (Figure 4).

Not all of the analyzed PA present slogans. However, when used, they often follow the name of the candidate, in bold type, but the size of the letters is smaller in comparison to the name of the candidate. The colors of the information about his affiliation and slogan match. This draws the viewer's attention, singling out the main information. Slogans are often short, concise, and in the form of nominal sentences. Cases of imperative sentences occur (Figures 4,5).

Call-and-visit information is not frequent. When used, it provides the address of the office, links, and QR codes to follow the social media of the party or the candidate. In order to specify the type of social media, the corresponding pictogram is used (Figures 5,8). 


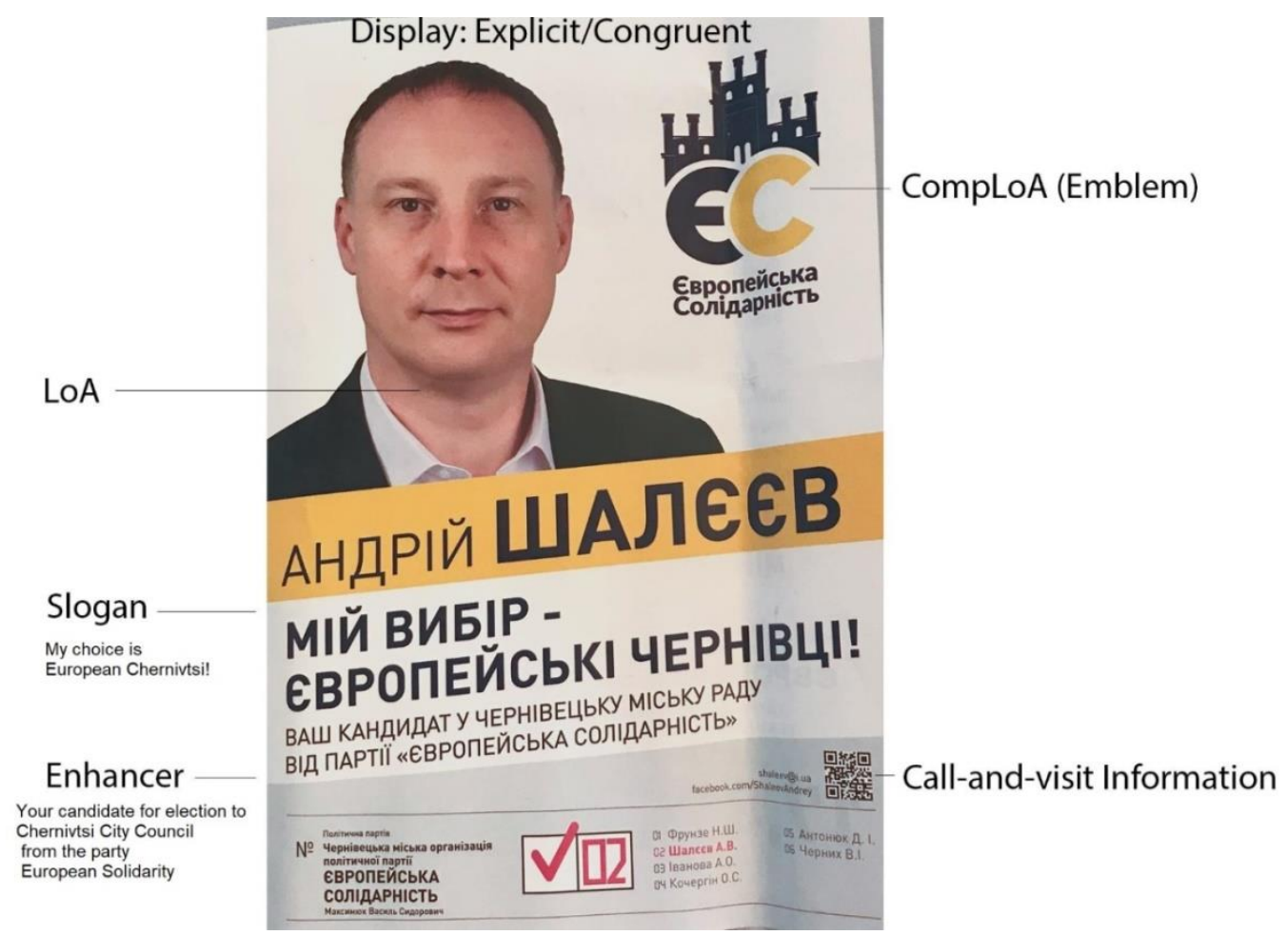

Figure 5. Multimodal Text of PA in Ukraine

\subsection{Interpretative Level}

Having outlined the literal level, we will next dwell on the sociocultural aspect involved (encoded) in the political advertisements. We believe that the multimodal content of political advertisements aiming to tap the voters' schemas, is sure to contribute to the voters' final political choice at the election. Consequently, the literal level of the multimodal analysis helps reveal the essence and the message of the multimodal material of political advertisements in Ukraine.

Display

Within the GSP of the multimodal texts in print advertisements (Cheong, 2004), the author uses the notion of display when talking about the types of meaning in the 'center of visual impact'/ CVI (Garcia, 2009). The following have been recognized: explicit, implicit, congruent, and incongruent (metaphorical).

The set of the political print advertisements represents few examples of implicit and incongruent display. Almost $95 \%$ of the examples represent explicit and congruent display.

As mentioned above, the lead in PA is represented by a photograph of a candidate. Aiming to catch the viewer's attention, and tap his schemas, the candidates in the photos are depicted with a friendly appearance and somewhat constrained smiles: 'serious', but not grim, faces suggest that the person is determined, confident, and competent. Broad smiles are not present in the analyzed print PA. The reason is also sociocultural: happy smiles give the impression of a carefree, unconcerned, untroubled person. Consequently, according to the existing schemas, such a person is completely happy, might be content with the current political and economic situation in the city or country, and thus potential voters will not opt for him, thus obscuring the prospect of a successful election for such politician. The situation refers to both male and female candidates.

When analyzing and generalizing the appearance and outfits of the candidates, we found one common feature that relates to $90 \%$ of male candidates: absence of tie (a regular constituent of smart style), which suggests the urge of the candidate to associate himself with the most of the voters, who tend to dress more casually. Within the set of leaflets, there are only two candidates dressed in office suits or with a tie. One example of PA is worth giving an interpretation, as the political candidate and the party he represents were at the top of the list of popular votes at the elections. He is captured wearing traditional Ukrainian attire, a vyshyvanka (embroidered shirt), and he is holding a little girl in a traditional embroidered dress (Figure 6). The candidate's appearance is confident, patriotic, and 
affectionate, aiming to transfer the following messages: he is a true Ukrainian who cares about the future (symbolized by the little girl), thus, he will try to contribute to the welfare of each resident of the city.

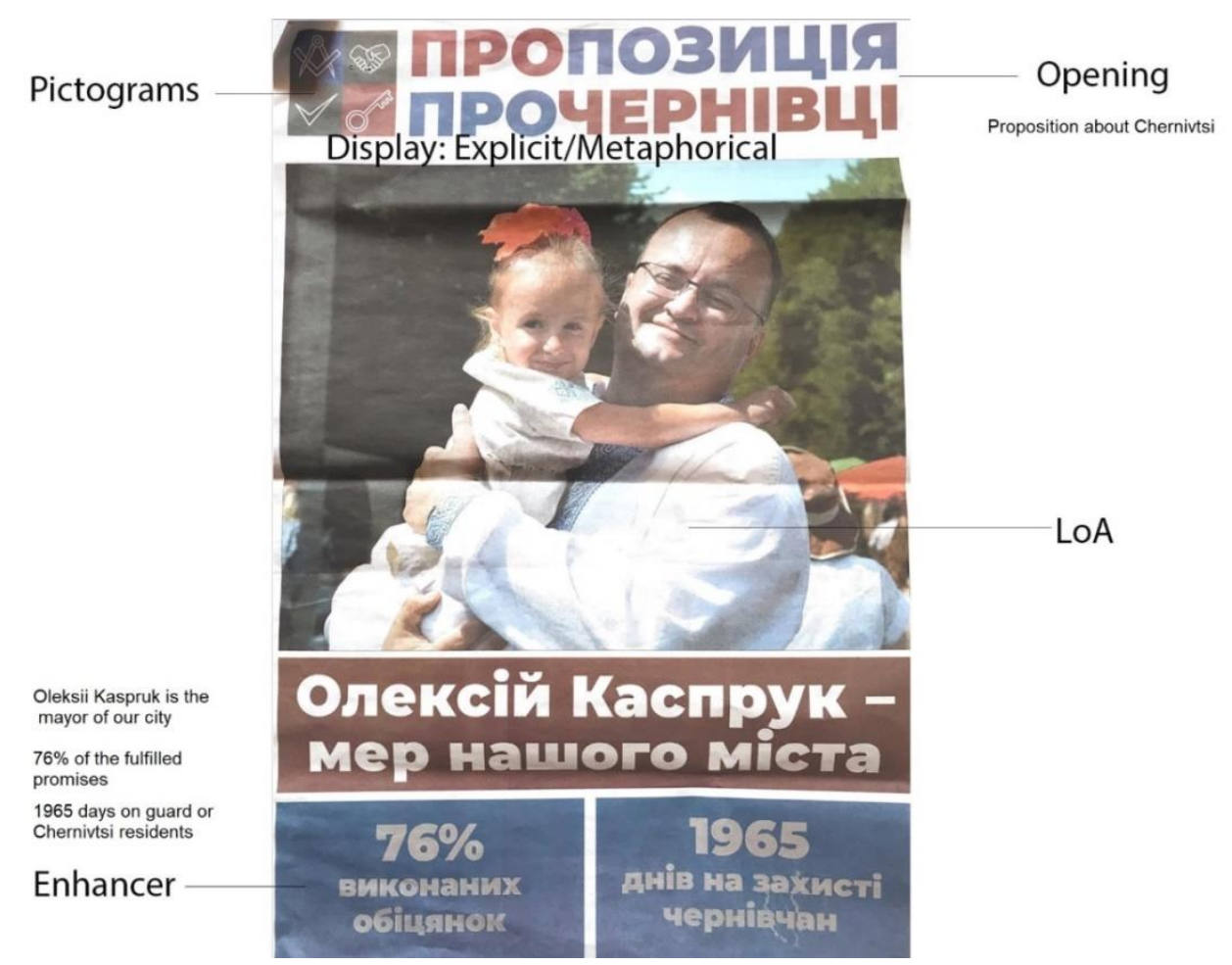

Figure 6. Multimodal Text of PA in Ukraine

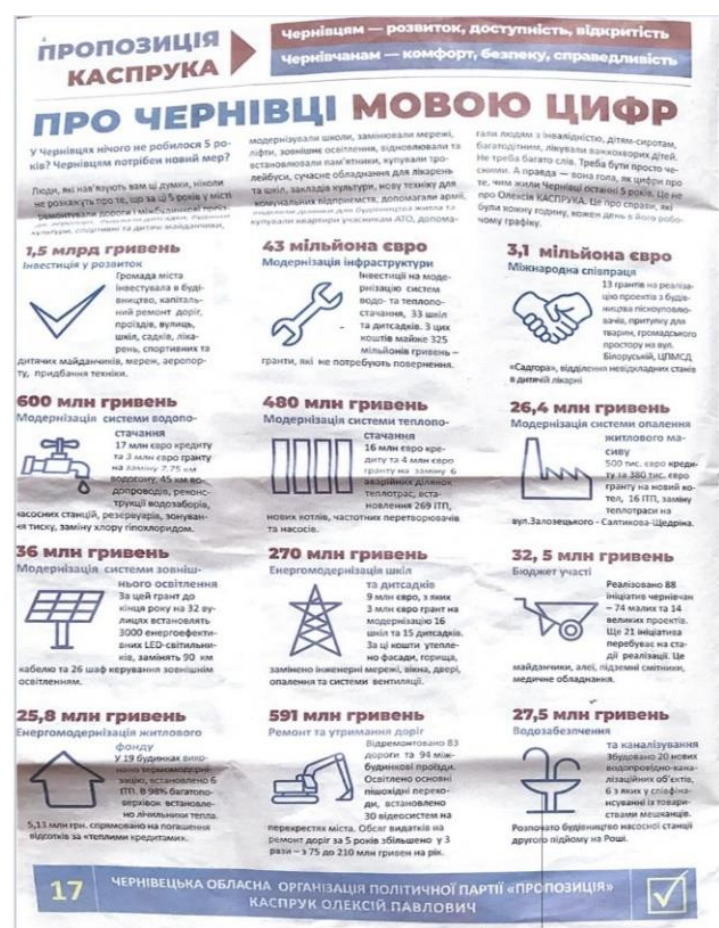

Pictogram

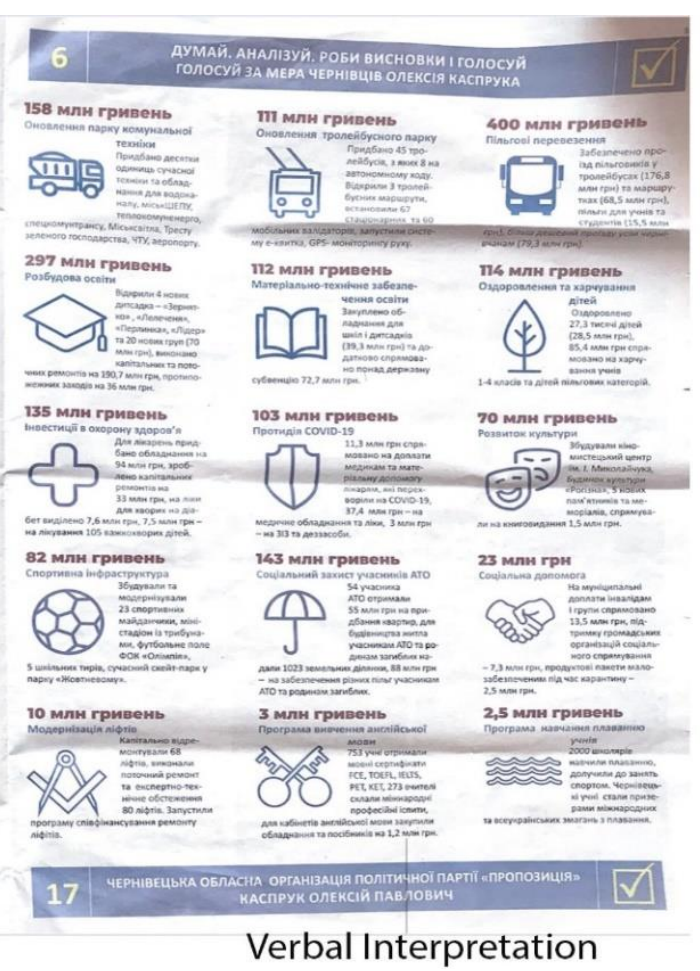

Verbal Interpretation

Figure 6.1. Manifesto Presenting the Set of Pictograms with Their Verbal Interpretation

In Figure 7, the Complement to the Locus of Attention is represented by a background picture of the city's famous architecture complex - the former Residence of Bukovynian and Dalmatian Metropolitans, currently Yurii Fedkovych Chernivtsi University. It is a very popular place to visit in Ukraine and non-verbally symbolizes the city 
of Chernivtsi, Ukraine. Thus, when the captions represent the candidate in the foreground and the architecture complex in the background, it aims to give the implicit information about the candidate's aim to work for the good of the city of Chernivtsi. (see Figure 7). In some cases, the Complement to the Locus of Attention is represented by the emblem of the political party (affiliation), implicitly activating the voters' schemas about their impressions concerning this party (Figures 2,5 ).

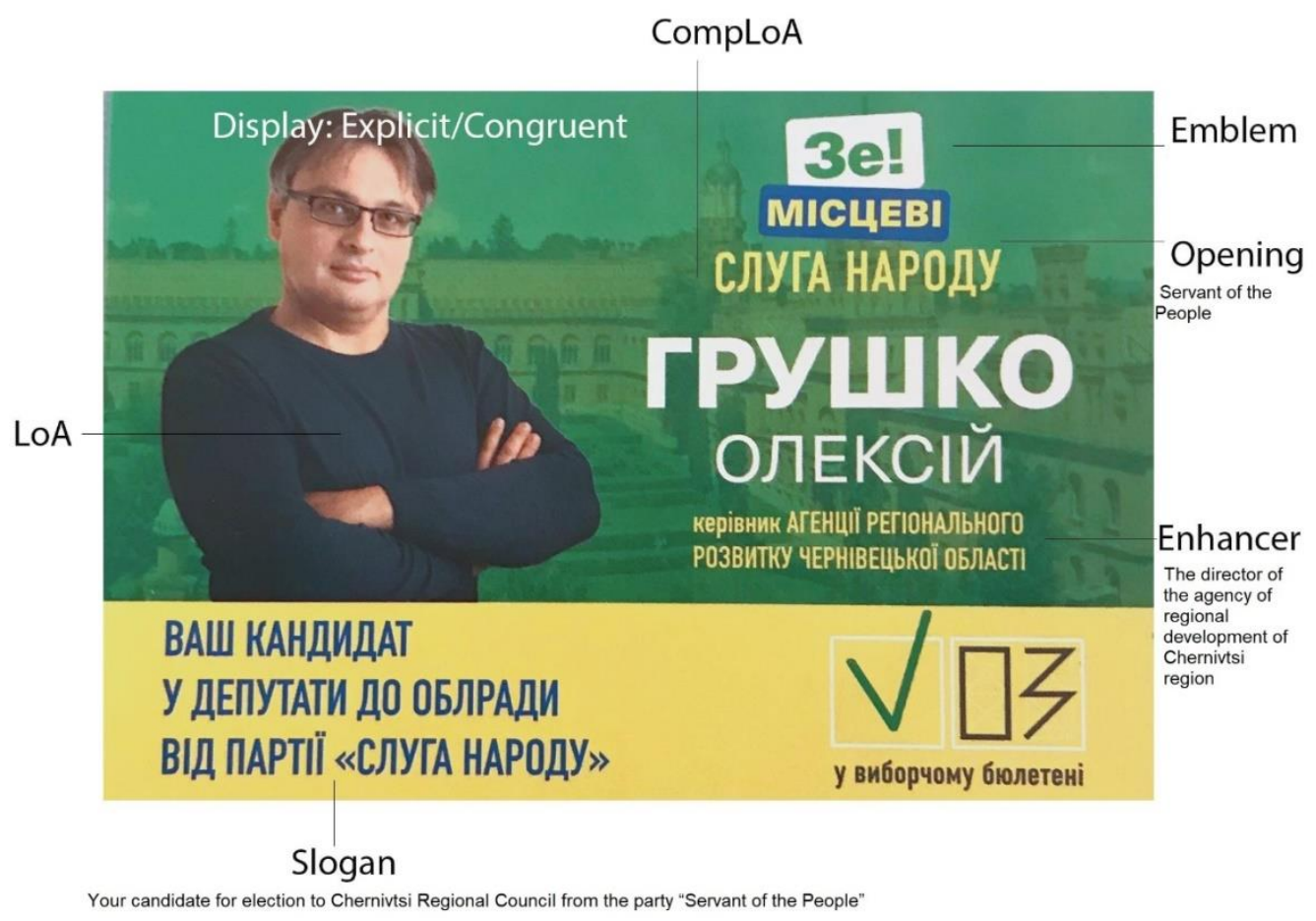

Figure 7. Multimodal Text of PA in Ukraine

\section{Discussion}

\section{Pictograms}

In $90 \%$ of cases, the most common pictogram is a checkmark in a box, combined with explicit verbal information about the corresponding number of the candidate, his name, and initials in the voting paper. The meaning of the pictogram is explicit, imploring the viewer to tick the box and thus help the candidate win the election.

Technique of the party to add a list of pictograms to the layout of the leaflets (Figures 3,6) represents another case of using pictograms implicitly. The pictograms have implicit meaning, so there was a risk of misinterpretation even by native Ukrainians. Although the manifesto of the party contained the same full list of the pictograms accompanied by the verbal information - the interpretation of each icon (Figure 6.1)- it is quite risky to apply such a technique; however, it can be beneficial when used effectively. A leaflet cannot contain much verbal information due to its form. When it is presented to a viewer, he may not be able to decode or interpret the pictograms accurately.

The viewer might ignore the set of pictograms or take an interest and look for the manifesto. In the latter case, he will find the interpretation and will be able to understand more about the party and the representatives.

There is also one example of PA where a pictogram serves as a Lead (LoA), representing the red target (see Figure 8). The image of the candidate serves as a Complement to the Locus of Attention, performing a gesture of pointing at someone (presumably the viewer) together with the verbal information «Цілком таємно»/translit: Tsilkom Tауетпо. (translation: Top Secret). The interpretation is the following: you are the one I've been looking for to inform about something, which is top-secret. You are the chosen one to whom I entrust this information. The last element of the layout is the contact information - the links to the social media. Following the link, the viewer will presumably find out more about the candidate. Similar to the aforementioned technique, it is another example of a riddle: the viewer must take interest to follow the links, scan the QR code, or visit the office for more information. In this case, all age groups have been considered: those at ease with technology can anytime check out the suggested information on 
social media as well as people who don't use technology or social media. In this case, the display is implicit and incongruent. However, it doesn't give any information about the candidate, affiliation party, or his number on the ballot. It is aimed at convincing the reader to take an interest and to follow the links to know more.

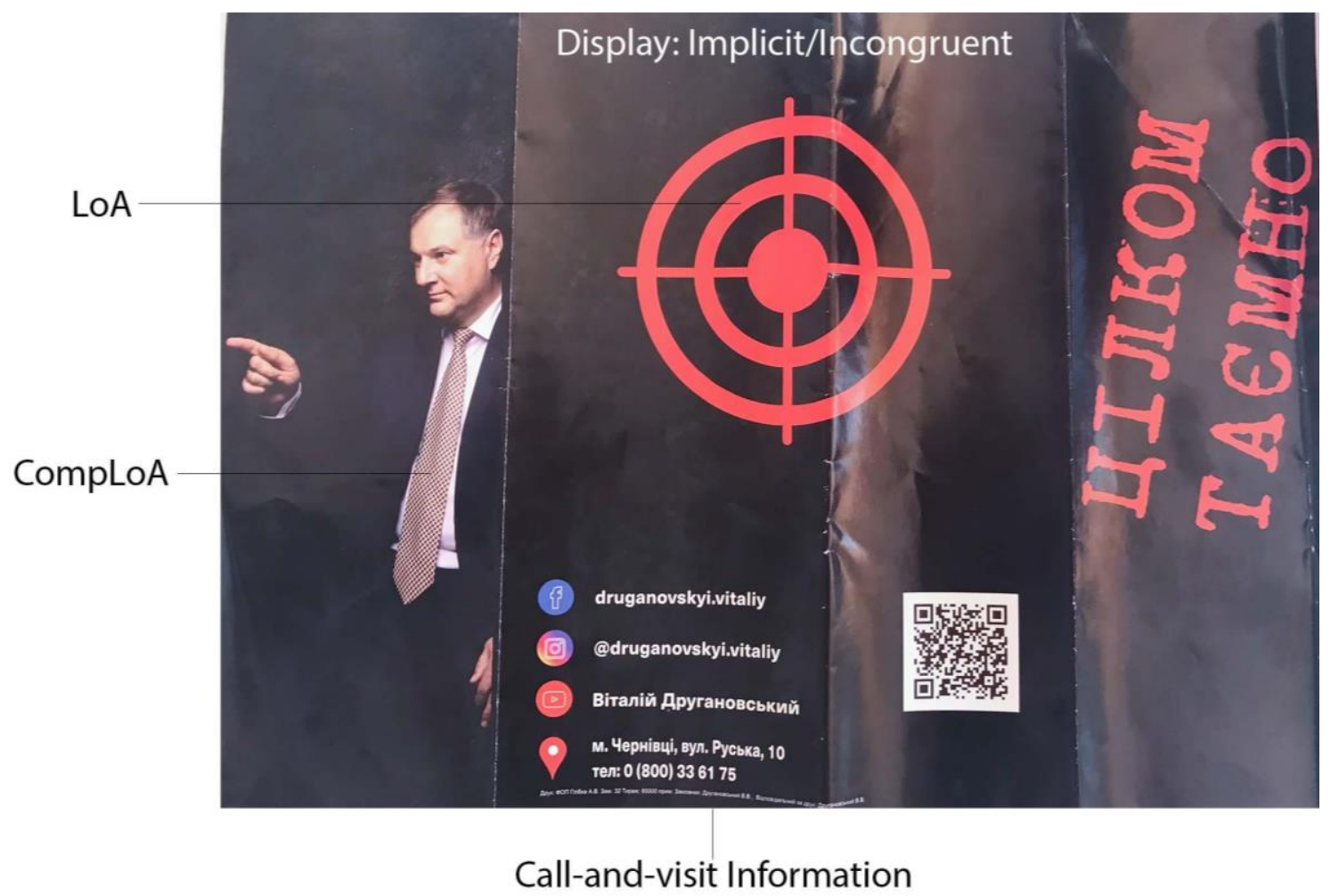

Figure 8. Multimodal Text of PA in Ukraine

The opening of the PA, represented by verbal information, is often explicit, provides the name of the candidate, his voting number, and party affiliation. Most prominent are the name and the voting number. They usually have a big font size, bold type, and matching color to activate the viewer's visual memory. There are cases of opening information, presenting a wordplay: «ПРОпозиція ПРОчернівці»/“PROposytsiia PROchernivtsi”(Proposition about Chernivtsi) (Figure 6). In Ukrainian, it can be cross-read, and there is such an intention to make the viewer do so (the text organization, coloring) (The semantics of the prefix ПPO/PRO is "about"), thus the meaning of this phrase is: "[I have] a proposition about Chernivtsi". The wordplay is also realized due to the fact, that the word Пропозиція "Proposytsiia" apart from its denotative meaning, stands for the corresponding political party.

However, there is an example in which no information about the candidate/party is given. This is the aforementioned implicit, incongruent display in Figure 8. It has been created to attract the viewer's attention, to trigger his curiosity. Implicitly it gives the impression that the candidate is innovative, thus he might solve many problems as a politician. It is worth mentioning that this technique follows the similar one applied during the Presidential Ukrainian election campaign by the team of the current President and his political party, who won popular votes in 2019. The candidate in Figure 8 has the same party affiliation.

The Enhancer in PA gives additional information about the candidate. Usually, the occupation or the indication of the political intentions, such as to become the next city mayor or local councilman, are provided. The indication of the candidate's day-to-day occupation aims at winning more respect among the voters, contributing to the successful image of the candidate. Information about the achievements of the candidate may be emphasized, as in the case with Figure 6, where the percentage of the implemented promises has been indicated. It seems to be a reasonable achievement to win the popular votes and beneficial to the candidate as he has already had the experience of the city mayor.

The PA analyzed in this study offer a wide range of slogans, phrases or short sentences aiming to evoke voters' patriotism. When used in the opening, it may contain the name of the political party, creating the effect of a wordplay. 
Such words are often polysemantic, as in the case with "Майбутнє Батьківщини в наших руках!"/ "Maibutnie batkivshchyny v nashykh rukakh"/ Translation: "The future of the motherland is in our hands" (see Figure 2). Batkivshchyna is the name of the party and its denotative meaning is "motherland". The slogan is patriotic and it is very likely that the meaning of the word Batkivshchyna is denotative, because the name of the party is given below. Slogan 2 in the same advertisement assures the voters of equality and social justice. In this case, the word Batkivshchyna is used as the name of the political party: "Порядок. Справедливість. Батьківщина" / Poryadok. Spravedlyvist. Batkivshchyna. / Order. Justice. Batkivshchyna. The first two nominal sentences are associated with the third one, assuring the voter of the party's most important aims.

More than one slogan can be used in a single advertisement. The sentences are imperative and slogans incorporate social, political, patriotic, and economic aspects of life, as in the Figure 4: "Прозорість і відкритість влади!”/Prozorist i vidkrytist vlady/ Transparency and openness of the authorities!”, “Народ має знати правду про чиновників і депутатів!"/ Narod maye znaty pravdu pro chynovnykiv i deputativ!/ Folks have to know the truth about the officials and deputies/ "Обирай свідомо!"/ Obyrai svidomo/ Make a conscious choice!

The slogans are political, trying to assure the voters about their rightful opportunity to control the deputies and to be the masters of the country and the city, stressing the fact that it is crucial to think, analyze, and not neglect the opportunity to vote. Slogans «Сіємо майбутнє разом!/Siyemo maibutnie razom/“We sow the future!"(Figure 1) or "Разом зробимо більше"/“Razom zrobymo bilshe!" / "Together we'll do more!" "Miy vybir - yevropeiski Chernivtsi"/ "My choice is European Chernivtsi!" can be referred to social (Figures 5,9). They indicate the candidates' inclusion, readiness to contribute and cooperate with the voters. The latter implies the urge of the candidate to associate with the voters on the basis of the shared interest. There are cases of economic slogans: “Справедливість і розвиток/ Spravedlyvist i rozvytok/ Justice and Development!” There is no related enhancer, so "economic development" is implied (Figure 3).

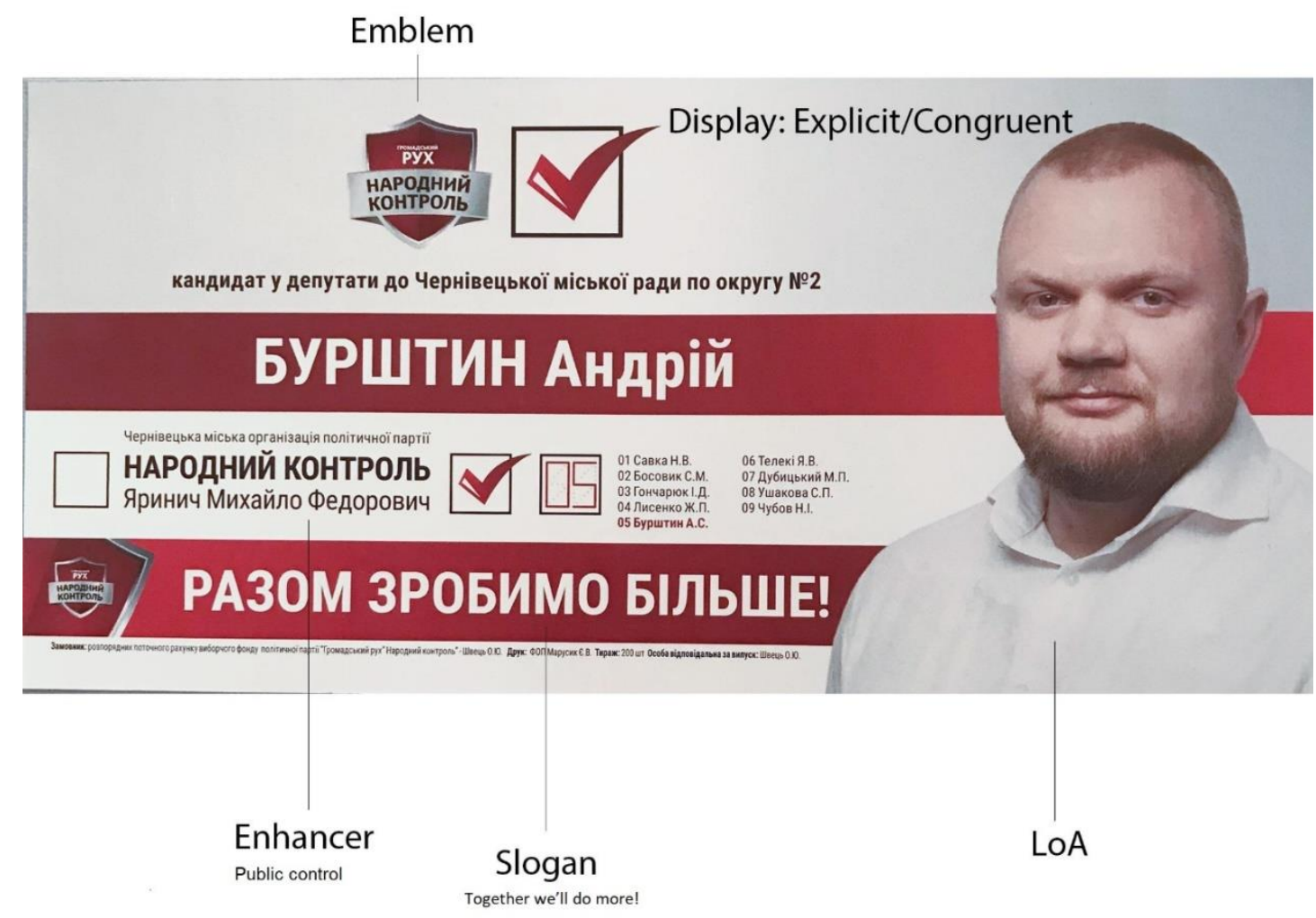

Figure 9. Multimodal Text of PA in Ukraine

When the verbal and non-verbal components of print PA are combined and the symbolism interpreted, it can be deduced that the predominant characteristics of PAs are explicit and congruent displays, as in $95 \%$ of the analyzed cases. Rare are the cases of implicit and metaphorical (incongruent) displays. They are not informative in terms of 
the candidate's name or affiliation. Rather, they aim to "beacon" the viewer to another source of information. There is one case where the display is explicit interspersed with the instances of incongruent meaning (Figure 6).

Below, Table 1 outlines the symbolism of the pictorial elements of print PA in Ukraine.

Table 1. Interpretation of the symbolic representation of the non-verbal level of PA

\begin{tabular}{|c|c|c|}
\hline No & Signifier & Signified/Representing \\
\hline $\mathbf{1}$ & photo & candidate \\
\hline 2 & appearance & funclusion, patriotism, confidence \\
\hline 3 & child & fure \\
\hline 4 & Ukrainian flag & the voter \\
\hline 5 & target & the choice to be made by the voter \\
\hline 6 & checkmark & $\begin{array}{c}\text { the political promises implemented by the candidates/the } \\
\text { promises to be implemented }\end{array}$ \\
\hline 7 & pictograms & the party emblem \\
\hline 8 & heart & the city of Chernivtsi, Ukraine \\
\hline 9 & $\begin{array}{c}\text { The Former Residence of Bukovynian and } \\
\end{array}$ & $\begin{array}{c}\text { Dalmatian Metropolitans, current Yurii Fedkovych } \\
\text { Chernivtsi University }\end{array}$
\end{tabular}

Table 2, given below, provides the types of slogans in the investigated cases.

Table 2. Interpretation of the symbolic representation of the verbal level of PA

\begin{tabular}{|l|l|l|}
\hline № & Signifier (Slogan) & Signified \\
\hline 1 & Patriotic & patriotism, national identity \\
\hline 2 & Social & justice, welfare \\
\hline 3 & Economic & economic equality \\
\hline 4 & Political & political convictions; shared political views \\
\hline
\end{tabular}

\section{Conclusions}

This research provides an analysis of the print political advertisements in Ukraine following the principles of Functional Systemic Approach and Generic Structure Potential of the print political advertisements. The data was collected in 2020 in Chernivtsi, Ukraine at the time of the election campaign. The total of the leaflets and newspaper advertisements is 25 . The analysis was carried out on two levels: literal and interpretative. The ideational meanings have been interpreted and the types of display of PA have been singled out. The visual (non-verbal) level of Ukrainian print political advertisements is represented by the lead (LoA and ComLoA), emblems, and pictograms. The verbal level comprises the opening information, enhancers, slogans, and call-and-visit information. In order to define the ideational meaning, we have endeavored to explicate the combination of verbal and pictorial constituents of PA. We have singled out the verbal and non-verbal signifiers and explicated the signified concepts. In order to make the aforementioned process successful, cultural knowledge and social experience of the researchers were incorporated in the decoding process.

The analysis has shown, that most of the candidates in their political campaign try to influence the voters by giving explicit information about their affiliation, number on the ballot, and enhancers to contribute to the image of a credible politician. Most of the displays are explicit and congruent. They often aim to inform the voters and, with the help of slogans, speak to the voters' social, political, patriotic, and economic viewpoints. The majority of PAs contains social slogans. They relate to common sense, activate a variety of schemas, and are universal. Political slogans relate to the possible changes in political life; patriotic slogans are not widely used. The reason may lie in the existing smothered features of nationalism and patriotism, which makes the candidates exploit such information with caution. Economic slogans are the least used. We presume that such slogans require accuracy: they can be measured and compared with publicly-accessible facts. Thus, in order to avoid possible disillusion of the voters in the future, candidates use abstract notions of justice, equality, and welfare.

Notwithstanding the variety of explicit and congruent displays, the implicit and incongruent have also been widely used in the election campaigns. Such advertisements contain less verbal information about the candidate but rather boost viewers' curiosity. It is deemed that such technique captures the viewer's attention and activates the schemas. Such advertisements are catchy and employ powerful visual material and symbolism to make the viewer realize that the candidate is worth their consideration. This technique can sometimes lead to misunderstanding, as for some of Published by Sciedu Press 
the voters taking extra steps is cumbersome. Thus, only the most conscientious voters will decide which course of action to take. Knowing the election outcomes, we may relate it to this study stating that the candidates whose advertisements involved symbolism and a comparatively greater amount of non-verbal information (implicit/incongruent display) led in the popular vote.

We assume that within the course of the following election campaigns the tradition of the predominance of non-verbal over the verbal information and the involvement of symbolism and visual metaphors in the print political advertisements will be pursued.

\section{References}

Alp, H. (2016). Political advertising and propaganda within spiral of silence-agenda setting theory. Journalism and Mass Communication, 6(1), 12-18. https://doi.org/10.17265/2160-6579/2016.01.002

Bowcher, W., \& Liang, J. (2016). GSP and multimodal texts. In Bowcher, W., Liang, J. (Eds.), Society in Language, Language in Society (pp. 251-274). Palgrave Macmillan. https://doi.org/10.1057/9781137402868_11

Cheong, Y. (2004). The construal of ideational meaning in print advertisements. In K. O'Halloran (Ed.), Multimodal Discourse Analysis: Systemic-Functional Perspectives (pp. 163-195). Continuum. Hal.

Dorofeev, D., \& Tomascikova, S. (2019). Evolving and changing paradigms of visual communication and the problem of the other in the postmillennial era. In Esse. English Studies in Albania, 2, 5-23. Retrieved from https://www.ceeol.com/search/article-detail id=922433

Finn, J. (2011). Visual communication and culture: images in action. Oxford University Press.

Gao, Y., \& Jonathan, J. W. (2020). New directions of systemic functional linguistics. Journal of World Languages, 6(1-2), 1-4. https://doi.org/10.1080/21698252.2020.1769916

García Rosales, D. F., \& Abuín Vences, N. (2019). The use of hypertextuality, multimedia, interactivity and updating on the websites of Spanish political parties. Communication \& Society, 32(1), 351-367. https://doi.org/10.15581/003.32.1.351-367

Garcia, M. (2009). Center of visual impact: where the eye goes first on page or on screen. The Mario Blog. Retrieved from https://garciamedia.com/blog/center_of_visual_impact_where_the_eye_goes_first_on_page_or_screen/

Halliday, M. (1978). Language as social semiotic: the social interpretation of language and meaning. Edward Arnold.

Hodge, B., \& Kress, G. (1988). Social Semiotics. Polity Press in association with Basil Blackwell.

Hromova, N., Kryvych, M., Chernihivska, N., Vinnytska, T., \& Bloshchynskyi, I. (2022). Forming critical reading skills in a low-intermediate class of English. World Journal of English Language, 12(1), 74-82. https://doi.org/10.5430/wjel.v12n1p74

Jewitt, C., \& Henriksen, B. (2016). Social semiotic multimodality. In N. Klug \& H. Stöckl (Eds.). Handbuch Sprache im Multimodalen Kontext (pp. 145-164). De Gruyter. https://doi.org/10.1515/9783110296099-007

Jewitt, C., Bezemer, J., \& O'Halloran, K. (2016). Introducing Multimodality. Routledge. https://doi.org/10.4324/9781315638027

Knox, J. S., \& Hao, J. (2020). Multimodality and systemic functional analysis. In C. A. Chappelle (Ed.), The Concise Encyclopedia of Applied Linguistics (pp. 801-811). Wiley Blackwell, Wiley.

Kovalevska T., \& Bekhta, I. (2019). Stylistic world of sound and signification text space: grapho-phonemics and paragraphemics of foregrounding. Scientific Journal of International Humanitarian University, 39(2), 4-9. https://doi.org/10.32841/2409-1154.2019.39.2.1

Kress, G. (2011). Multimodal discourse analysis. In J. P. Gee \& M. Handford (Eds.), The Routledge Handbook of Discourse Analysis (pp. 35-50). Routledge. Retrieved from https://www.routledgehandbooks.com/doi/10.4324/9780203809068.ch3

Kress, G., \& Leeuwen, T. (2006). Reading images: The grammar of visual design. Routledge. https://doi.org/10.4324/9780203619728

O'Halloran, K. (2009). Multimodal analysis and digital technology. In A. Baldry \& E. Montagna (Eds.), Interdisciplinary Perspectives on Multimodality: Theory and Practice. Proceedings of the Third International Conference on Multimodality. Palladino. Retrieved from 
https://webcache.googleusercontent.com/search?q=cache:OfUlrYwzjfkJ:https://multimodal analysislab.org/_docs/pubs02Multimodal_Analysis_and_Tech.pdf $+\& c d=1 \& h l=r u \& c t=c l n k \& g=u a$

Pacheco-Costa, A., \& Guzmán-Simón, F. (2020). Developing multimodal narrative genres in childhood: an analysis of pupils' written texts based on systemic functional linguistics theory. Education Sciences 10(11), 342. https://doi.org/10.3390/educsci10110342

Savitri, M. T., \& Rosa, R. N. (2019). A study of multimodal analysis in smartphone advertisement. E-Journal English Language and Literature, 8(3), 229-240. https://doi.org/10.24036/ell.v8i3.105767

Soloviova, O., Bloshchynskyi, I., Tsviak, L., Voitiuk, O., \& Mysechko, O. (2021). Compatibility of semantics of suffixes with gender assignment in Old English. International Journal of English Language and Literature Studies, 10(3), 224-235. https://doi.org/10.18488/journal.23.2021.103.224.235

Tokgöz, O. (2010). Elections, political communication and political advertising. İmge Publishing.

Yesypenko, N., Pavlovych, T., Migorian, O., Bloshchynskyi, I., \& Mysechko, O. (2022). Metaphorical representation of anthropomorphic concepts in British and American fairy tales. Journal of Language and Linguistic Studies, 18(Special Issue 1), 18-33.

\section{Copyrights}

Copyright for this article is retained by the author(s), with first publication rights granted to the journal.

This is an open-access article distributed under the terms and conditions of the Creative Commons Attribution license (http://creativecommons.org/licenses/by/4.0/). 